\title{
PROTEOMIC ANALYSIS OF SAFFRON (Crocus sativus L.) GROWN UNDER CONDITIONS OF CADMIUM TOXICITY
}

\author{
ANÁLISE PROTEÔMICA DO AÇAFRÃO (Crocus sativus L.) CULTIVADO SOB \\ CONDIÇÕES DE TOXICIDADE POR CÁDMIO
}

\author{
Junfeng RAO ${ }^{1 *}$; Weide $\mathrm{LV}^{\mathbf{1}}$; Jumei YANG ${ }^{2}$ \\ 1. Hangzhou Vocational and Technical College, Hangzhou 310018, China; 2. Panan People's Hospital, Jinhua 322300, China. \\ raojunfenghz@163.com; 13588867756@139.com
}

\begin{abstract}
Cd is a highly detrimental global environmental pollutant. Plants have evolved complex defense mechanisms as an adaptation to against Cd toxicity. In this study, a pot experiment was performed to evaluate the protein profile of saffron in response to $\mathrm{Cd}$ stress. Fifteen proteins were found to be up-regulated in the leaves of plants under $\mathrm{Cd}$ stress and were primarily related to metabolism, signal transduction, stress and defense response and energy. Eleven proteins were found to be down-regulated following $\mathrm{Cd}$ treatment, including ribulose bisphosphate carboxylase/oxygenase (Rubisco), ferredoxin-NADP reductase, a $70 \mathrm{kDa}$ heat shock-related protein and three protein synthesis-associated proteins. The results provide valuable insights regarding the molecular mechanism of saffron in response to Cd toxicity and the possible utilization of genetic resources in developing Cd tolerant/low-accumulation saffron.
\end{abstract}

KEYWORDS: Heavy metal. Proteome. Response. Photosynthesis. Saffron

\section{INTRODUCTION}

Cadmium (Cd) pollution has become a serious environmental issue as a consequence of human activities (KULIK et al., 2012; CAO et al. 2014a). Since the occurrence of "Itai-Itai disease" during the 1950-60s in Japan, Cd pollution has generated worldwide concern (CAO et al., 2013). Moderate $\mathrm{Cd}$ pollution in the soil could result in considerable $\mathrm{Cd}$ accumulation in cereals and subsequently pose a significant threat to human health via the food chain (URAGUCHI and FUJIWARA 2012). In plants, having no biological function and high toxicity, $\mathrm{Cd}$ can lead to various problems such as the inhibition of photosynthesis and transpiration, alteration of ion homeostasis, and poor quality products (VESELOV et al., 2003; DENG et al., 2014).

$\mathrm{Cd}$ affects many important physiological and biochemical processes in plants such as photosynthesis and nutrient homeostasis, which in turn inhibits normal plant growth and development (CLIJSTERS; VANASSCHE, 1985; CAO et al., 2014b). To defend against the detrimental effects of $\mathrm{Cd}$, plants have evolved many detoxification mechanisms, including $\mathrm{Cd}$ chelation and vacuolar compartmentalization (HALL, 2002). For example, OsHMA3 (a P-type ATPase 3) has been found to play a key role in xylem $\mathrm{Cd}$ transport by mediating vacuolar compartmentalization in the root cells of rice (URAGUCHI; FUJIWARA, 2012). OsDEP, encoding a Cys-rich $\mathrm{G}$ protein $\gamma$ subunit, has also been found to play an important role in $\mathrm{Cd}$ tolerance
(KUNIHIRO et al., 2013). However, the regulatory mechanism of $\mathrm{Cd}$ tolerance in saffron is still unknown. Saffron (Crocus sativus), a perennial herb belonging to the Iridaceae, is heavily used in traditional medicine because of its anticancer, antioxidative, antidepressant, anticonvulsant and learning- and memory-enhancing properties (MACCARONE et al., 2008; SHAMSA et al., 2009; ASADI et al., 2014). There is only one study which reports the effect of $\mathrm{Cd}$ on saffron and they only investigated the heavy metal concentration in saffron (ABOU-ARAB; ABOU DONIA 2000). However, the molecular mechanisms underlying the response to $\mathrm{Cd}$ toxicity in saffron remain unclear. Comparative proteomic analysis provides a powerful tool to identify the proteins expressed under biotic and abiotic stress (XU et al., 2010). No study has reported the effect of $\mathrm{Cd}$ on protein expression in saffron. Thus, the present study was carried out to identify the protein profiles of saffron under $\mathrm{Cd}$ stress. These results will be useful for understanding the effect of $\mathrm{Cd}$ on saffron at the proteomic level, and may identify key proteins or genes for the genetic enhancement of tolerance to Cd toxicity in plants.

\section{MATERIAL AND METHODS}

\section{Experimental design}

A pot experiment was conducted in the greenhouse of Hangzhou Vocational \& Technical College, Hangzhou, China. A single saffron genotype (Crocus sativus L.) was used. Two $\mathrm{kg}$ of 
commercial soil was weighed and placed in each pot $(5 \mathrm{~L}, 20 \mathrm{~cm} \times 22 \mathrm{~cm} \times 4 \mathrm{~cm})$. The soil was then artificially contaminated by adding a Cd solution to create a Cd treatment with $20 \mathrm{mg} \mathrm{kg}^{-1} \mathrm{Cd}$; the control contained no added $\mathrm{Cd}$. Following addition of the $\mathrm{Cd}$ solution, the soil was allowed to equilibrate for a period of $30 \mathrm{~d}$ in the greenhouse. The saffron bulbs were placed on a shaded shelf for germination. After 60 days, uniform healthy plants were selected and transplanted into the pots. Four plants were planted per pot. The experiment used a completely randomized design with 4 replicates. Plant samples were collected after 30 days of treatment for protein analysis. The fresh leaves were immediately frozen in liquid nitrogen and stored at $80{ }^{\circ} \mathrm{C}$ until analysis.

\section{Protein analysis}

Total leaf protein was extracted according to the protocol of Carpentier et al. (2005). The protein content was measured with a standard Bradford assay using bovine serum albumin as the standard (Bio-Rad, Hercules, CA, USA). Protein spots were separated using two-dimensional gel electrophoresis (2-DE) and then visualized by silver staining of the analytical gels (BAH et al., 2010; DAI et al., 2013).

The gels were scanned and calibrated with a PowerLook1100 scanner (UMAX), and protein spots were then analyzed using GE HealthCare Software (Amersham Biosciences). Only those spots with significant and reproducible changes $(P \leq 0.05)$ were considered to be differentially expressed proteins. The selected protein spots were excised from the stained gels and digested with a trypsin solution using a Spot Handling Workstation (Amersham Biosciences). Trypsin digestion and peptide extraction were conducted according to the protocol of Bah et al. (2010). The digested peptide masses were analyzed using a MALDI-TOF-TOF mass spectrometer (ABI4700 System, USA). The corresponding parameters were based on BAH et al. (2010). Peptide mass fingerprint data were matched to the NCBInr database using the Profound program under $50 \mathrm{ppm}$ mass tolerance. Data were processed using Data Explorer software and proteins were unambiguously identified by searching against a comprehensive non-redundant sequence database using the MASCOT software search engine (http://www.matrixscience.com). Proteins with change of $>1.5$-fold or $<-1.5$-fold and a $\mathrm{P}$ value $<0.05$ were considered differentially expressed.

\section{Statistical analysis}

Statistical analyses were performed using Data Processing System (DPS) statistical software.

\section{RESULTS}

The average number of leaf protein spots on the 2-DE gels for the Cd treatment and the control was 1594 and 1588, respectively. Of these, 94 and 64 protein spots were observed to be significantly up-regulated ( $>1.5$-fold change) and down-regulated ( $<-1.5$-fold change), respectively, after Cd treatment compared with the control. Fifteen (A1-A15) and 11 (B1-B11) protein spots were successfully identified by MALDI-TOF-TOF-MS (Tables 1 and 2, Figs 1 and 2). The functions of the fifteen proteins that were significantly up-regulated in the $\mathrm{Cd}$ treatment were categorized as metabolism (46.7\%), signal transduction $(26.7 \%)$, stress and defense response $(6.7 \%)$, energy $(6.7 \%)$ and unknown function (13.3\%) (Table 1). Seven proteins were involved in metabolism: 5-methyltetrahydropteroyltriglutamatehomocysteine methyltransferase (A1), glyceraldehyde-3-phosphate dehydrogenase (A2), glutamine synthetase (A3), tubulin beta chain (A4), 2,3-bisphosphoglycerate-independent

phosphoglycerate mutase (A5), alpha-1,4-glucanprotein synthase (A6) and 3 beta-hydroxysteroiddehydrogenase/decarboxylase isoform 1 (A7). The other up-regulated proteins were as follows: signal transduction (c.f. A8 and A9, S-adenosylmethionine synthetase 1; A11, 1-aminocyclopropane-1carboxylate oxidase), stress and defense (A12, pathogenesis-related protein 10), energy (A13, ATP synthase subunit alpha) and unknown function (A14 and A15).

Table 1. Proteins whose expression were significantly up-regulated under $\mathrm{Cd}$ stress

\begin{tabular}{|c|c|c|c|c|c|c|c|c|c|}
\hline $\begin{array}{l}\text { Spot } \\
\text { ID }\end{array}$ & Protein name & $\begin{array}{l}\text { Accession } \\
\text { number }\end{array}$ & $\begin{array}{l}\text { MW } \\
\text { (Da) }\end{array}$ & $\mathrm{pI}$ & $\mathrm{FC}$ & Score & $\begin{array}{c}\text { Cov } \\
\%\end{array}$ & MP & PF \\
\hline A1 & $\begin{array}{l}5- \\
\text { methyltetrahydropteroyltriglutamate- } \\
\text {-homocysteine methyltransferase } \\
\text { (Catharanthus roseus) }\end{array}$ & METE_CATRO & 85089 & 6.10 & $10^{6}$ & 126 & 11 & 7 & $\mathrm{M}$ \\
\hline A2 & $\begin{array}{l}\text { Glyceraldehyde-3-phosphate } \\
\text { dehydrogenase, (Oryza sativa) }\end{array}$ & G3PC_ORYSI & 36561 & 6.61 & $10^{6}$ & 132 & 10 & 4 & M \\
\hline
\end{tabular}


A3 Glutamine synthetase (Musa acuminata)

A4 Tubulin beta chain (Cicer arietinum)

A5 2,3-bisphosphoglycerateindependent phosphoglycerate mutase (Cryophytum crystallinum)

A6 Alpha-1,4-glucan-protein synthase (Pisum sativum)

A7 3beta-hydroxysteroiddehydrogenase/decarboxylase isoform 1 (Arabidopsis thaliana)

A8 S-adenosylmethionine synthetase 1 (Populus trichocarpa)

A9 S-adenosylmethionine synthetase 1 (Populus trichocarpa)

A10 Auxin-responsive protein IAA18 (Arabidopsis thaliana)

A11 1-aminocyclopropane-1-carboxylate oxidase (Persea americana)

A12 Pathogenesis-related protein 10 (Crocus sativus)

A13 ATP synthase subunit alpha, chloroplastic (Eucalyptus globulus)

A14 Uncharacterized protein (Triticum aestivum)

A15 Uncharacterized protein (Musa acuminata)

$\begin{array}{cccccccc}\text { MOSO22_MUSAM } & 39428 & 6.03 & 1.80 & 94 & 16 & 4 & \text { M } \\ \text { TBB_CICAR } & 51171 & 4.75 & 2.90 & 65 & 25 & 7 & \text { M } \\ \text { PMGI_MESCR } & 61316 & 5.39 & 3.12 & 141 & 13 & 7 & \text { M } \\ \text { UPTG_PEA } & 42059 & 5.73 & 1.50 & 110 & 17 & 6 & \text { M } \\ \text { HSDD1_ARATH } & 48493 & 8.89 & 3.86 & 29 & 2 & 1 & \text { M } \\ & & & & & & & \\ \text { METK1_POPTR } & 43642 & 5.68 & 10^{6} & 245 & 20 & 7 & \text { ST } \\ \text { METK1_POPTR } & 43642 & 5.68 & 4.05 & 236 & 20 & 7 & \text { ST } \\ \text { IAA18_ARATH } & 29936 & 9.26 & 2.89 & 61 & 13 & 6 & \text { ST } \\ \text { ACCO_PERAE } & 36453 & 5.08 & 10^{6} & 42 & 4 & 1 & \text { ST } \\ \text { E5D8G2_CROSA } & 17502 & 6.08 & 22.58 & 93 & 37 & 5 & \text { SD } \\ \text { ATPA_EUCGG } & 55535 & 5.15 & 1.52 & 319 & 24 & 12 & \text { E } \\ \text { W5A1P2_WHEAT } & 192765 & 6.74 & 1.80 & 72 & 12 & 16 & \text { U } \\ \text { M0TI68_MUSAM } & 32323 & 5.23 & 1.85 & 51 & 4 & 1 & \text { U }\end{array}$

Cov, coverage; E, energy; FC, fold change; M, metabolism; MP, matched peptides; PF, Putative function; U, unknown; SD, stress and defense response; ST, signal transduction.

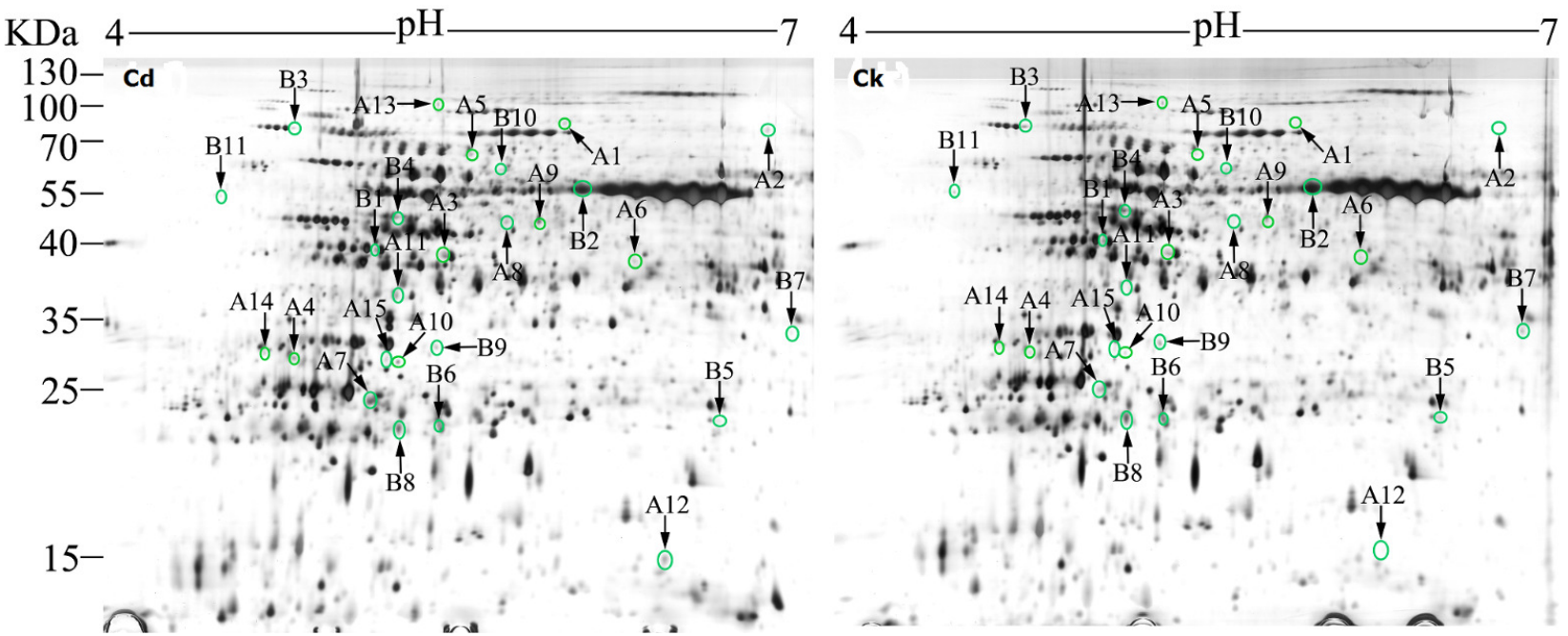

Figure 1. Representative 2-DE maps of saffron leaf proteins isolated from $\mathrm{Cd}$ and control treatment. Total proteins were extracted and separated by 2-DE. In IEF, $100 \mathrm{mg}$ proteins were loaded onto $\mathrm{pH} 4-7$ IPG strips $(24 \mathrm{~cm}$, linear). SDS-PAGE was performed with $12.5 \%$ gels. The spots were visualized by silver staining. Differentially accumulated protein spots are indicated by green sashes. Fifteen higher expressed spots (A) and eleven suppressed (B) spots are shown in the maps. 
Table 2. Proteins whose expression were significantly down-regulated under Cd stress

\begin{tabular}{|c|c|c|c|c|c|c|c|c|c|}
\hline $\begin{array}{l}\text { Spot } \\
\text { ID }\end{array}$ & Protein name & Accession number & $\begin{array}{l}\text { MW } \\
\text { (Da) }\end{array}$ & $\mathrm{pI}$ & $\mathrm{FC}$ & Score & $\begin{array}{c}\text { Cov } \\
\%\end{array}$ & MP & $\mathrm{PF}$ \\
\hline B1 & $\begin{array}{l}\text { Ribulose bisphosphate } \\
\text { carboxylase/oxygenase activase, } \\
\text { (Oryza sativa) }\end{array}$ & RCA_ORYSJ & 51764 & 5.43 & -2.85 & 253 & 16 & 8 & $\mathrm{M}$ \\
\hline B2 & $\begin{array}{l}\text { Ribulose bisphosphate carboxylase } \\
\text { large chain (Isophysis tasmanica) }\end{array}$ & RBL_ISOTA & 52248 & 5.87 & -1.58 & 386 & 22 & 12 & M \\
\hline B3 & $\begin{array}{l}\text { Stromal } 70 \text { kDa heat shock-related } \\
\text { protein, chloroplastic (Pisum } \\
\text { sativum) }\end{array}$ & HSP7S_PEA & 75583 & 5.22 & -2.97 & 170 & 17 & 9 & SD \\
\hline B4 & $\begin{array}{l}\text { Eukaryotic initiation factor } 4 \mathrm{~A} \\
\text { (Triticum aestivum) }\end{array}$ & IF4A_WHEAT & 47183 & 5.31 & -2.11 & 59 & 14 & 7 & PS \\
\hline B5 & $\begin{array}{l}\text { 30S ribosomal protein } 2 \text {, chloroplastic } \\
\text { (Spinacia oleracea) }\end{array}$ & RRP2_SPIOL & 28390 & 8.42 & -2.61 & 91 & 10 & 5 & PS \\
\hline B6 & Chaperonin (Zea mays) & B4F848_MAIZE & 25796 & 8.49 & -2.68 & 76 & 33 & 6 & PS \\
\hline B7 & $\begin{array}{l}\text { Ferredoxin-NADP reductase, leaf } \\
\text { isozyme, (Pisum sativum) }\end{array}$ & FENR1_PEA & 40454 & 8.56 & -7.00 & 118 & 16 & 7 & $\mathrm{~T}$ \\
\hline B8 & $\begin{array}{l}\text { Ferritin-1, chloroplastic (Glycine } \\
\max \text { ) }\end{array}$ & FRI1_SOYBN & 28204 & 5.73 & -1.50 & 104 & 9 & 5 & $\mathrm{~T}$ \\
\hline B9 & Knotted1 (Spinifex sericeus) & A3RCP6_9POAL & 9309 & 4.98 & -1.50 & 78 & 92 & 7 & $\operatorname{Tr}$ \\
\hline B10 & $\begin{array}{l}\text { Uncharacterized protein (Hordeum } \\
\text { vulgare) }\end{array}$ & MOUGX1_HORVD & 91892 & 6.51 & -3.20 & 76 & 22 & 15 & $\mathrm{U}$ \\
\hline B11 & $\begin{array}{l}\text { Uncharacterized protein } \\
\text { (Brachypodium distachyon) }\end{array}$ & I1HXX4_BRADI & 39825 & 4.50 & -2.68 & 72 & 8 & 5 & $\mathrm{U}$ \\
\hline
\end{tabular}

Cov, coverage; FC, fold change; M, metabolism; MP, matched peptides; PF, Putative function; PS, protein synthesis; U, unknown; SD, stress and defense response; $\mathrm{T}$, transport; $\mathrm{Tr}$, transcription.

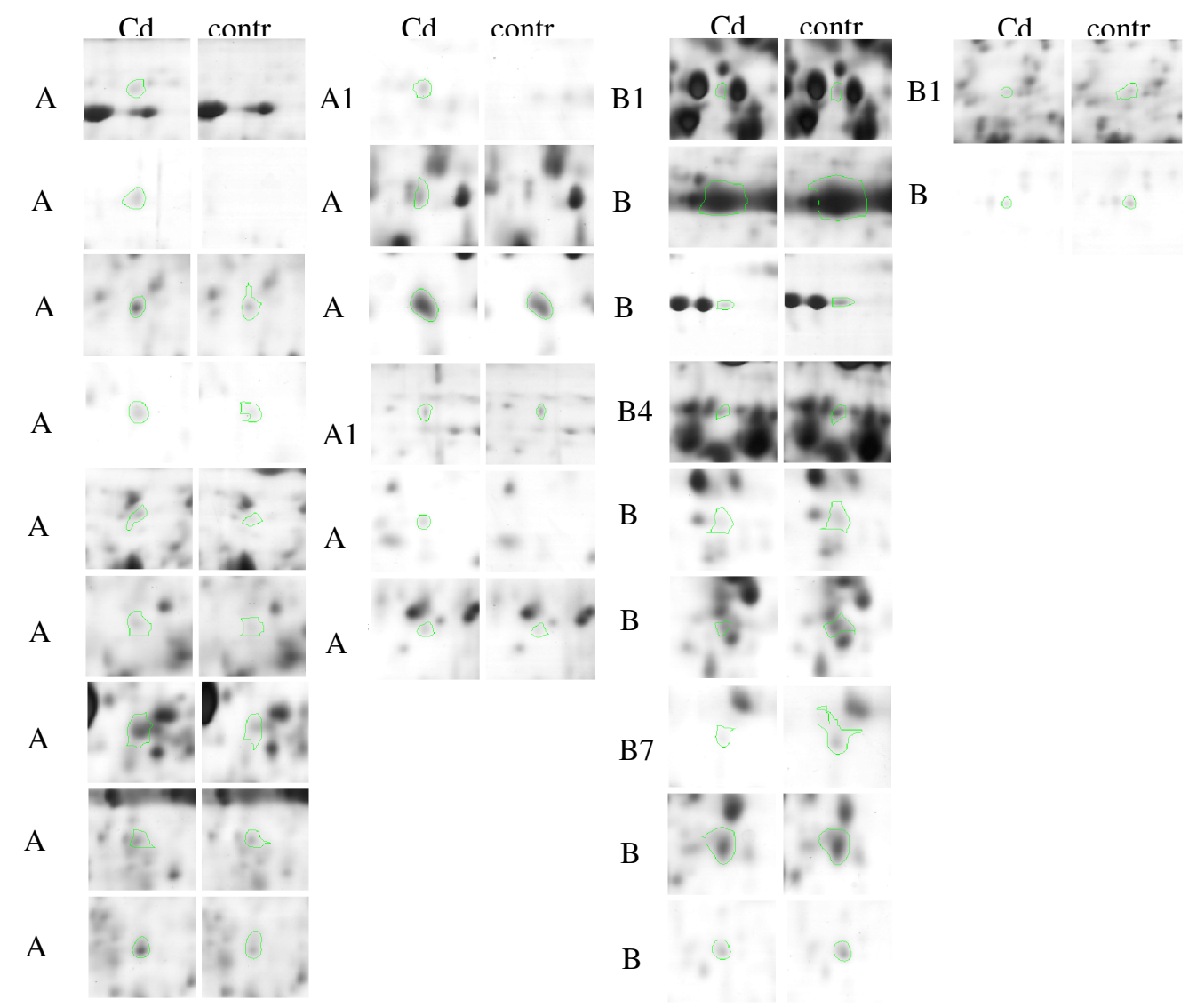

Figure 2. The spot view of individual identified spots, being up-regulated (A) and down-regulated (B) after Cd treatment. 
The 11 suppressed proteins (Cd vs. control) belonged to 6 functional categories (Table 2; Fig. 2). Two were found to play key roles in photosynthesis: ribulose bisphosphate carboxylase/oxygenase activase (B1) and ribulose bisphosphate carboxylase large chain (B2). There were 3 protein synthesisrelated proteins: eukaryotic initiation factor $4 \mathrm{~A}$ (B4), 30S ribosomal protein 2 (B5) and chaperonin (B6). One stress and defense response protein, stromal $70 \mathrm{kDa}$ heat shock-related protein (B3), and 1 transcription-related protein, Knotted1 (B9), were significantly down-regulated by -2.97 -fold and 1.50-fold, respectively, after $\mathrm{Cd}$ treatment. Two transport-related proteins, ferredoxin-NADP reductase (B7) and ferritin-1 (B8), were also identified. In addition, 2 uncharacterized proteins (B10 and B11) were also clearly down-regulated.

\section{DISCUSSION}

$\mathrm{Cd}$ is believed to induce damage even at very low concentrations, not only affecting many important physiological processes but also reducing the yield and quality of plants (CAO et al., 2013, 2014). Saffron is a traditional precious herb. Our previous study found that $\mathrm{Cd}$ significantly suppressed saffron growth and considerable $\mathrm{Cd}$ was accumulated (data unpublished). In this study, 15 and 11 protein spots were up-regulated and downregulated, respectively, in response to $\mathrm{Cd}$ stress (Fig. 2).

Among the 15 proteins with elevated expression, 4 are involved in signal transduction: $\mathrm{S}$ adenosylmethionine synthetase 1 (SAMS, A8 \& A9), 1-aminocyclopropane-1-carboxylate oxidase (ACCO, A11) and auxin-responsive protein IAA18 (A10). It has been found that the ethylene (ET) signaling pathway plays a fundamental role in the response to abiotic stress, including $\mathrm{Cd}$ stress (FUJITA et al. 2006). SAMS has long been considered to have a house-keeping function and plays a crucial role in ET synthesis (DAI et al. 2013). In addition, ACCO catalyzes the terminal step of ET synthesis (HERBETTE et al. 2006; CAO et al. 2014). Hence, up-regulation of SAMS and ACCO in response to Cd stress could contribute to ET synthesis, which subsequently activates additional Cd-responsive genes. Auxin-responsive protein IAA18 was also significantly up-regulated (Table 1). Therefore, it is necessary to study the relationship between the ET and auxin signaling pathways in response to Cd toxicity.

Seven of the proteins identified as upregulated were involved in metabolism (Table 1). Glyceraldehyde-3-phosphate dehydrogenase
(GAPDH, A2) plays a key role in glycolysis. VESCOVI et al. (2013) found that the cytosolic GAPDH isoenzyme GAPC1 may play a role in signaling oxidative stress or protection in Arabidopsis roots under $\mathrm{Cd}$ stress. Glutamine synthetase (GS, A3) catalyzes the formation of glutamate, which is an important component of reduced glutathione and phytochelatins (PCs). Rana et al. (2008) observed that the expression of cytosolic GS was induced by $\mathrm{Cd}$ and salt stress. Studies have found that beta-tubulin and alpha-1,4glucan-protein synthase are involved in plant cell wall metabolism (SPOKEVICIUS et al., 2007; JIN et al., 2011). Lee et al. (2010) also found that expression of alpha-1,4-glucan-protein synthase (A6) was significantly elevated. Membrane-bound ATPases provide energy and an $\mathrm{H}^{+}$gradient for the co-transport of copper, cobalt, lead, and $\mathrm{Cd}$, with protons used for the detoxification of these metal ions in plants (CAO et al. 2014). CAO et al. (2014) found that transcripts of V-ATPase were significantly elevated in a Cd-tolerant barley genotype but were not affected in a Cd-sensitive genotype. Kieffer et al. (2008) found that pathogenesis-related proteins showed a dramatic increase in expression. In our study, these proteins were all significantly up-regulated under Cd stress. Plants have evolved sophisticated defense mechanisms as an adaption to $\mathrm{Cd}$ stress. The results of this study suggest that $\mathrm{Cd}$ may induce signal molecules (ET) that subsequently activate Cdresponsive proteins, elevate the expression of antioxidant-related proteins that could scavenge the Cd-induced accumulation of ROS, and transport $\mathrm{Cd}$ into vacuoles and sequestrate $\mathrm{Cd}$ in cell walls, which would contribute to a decrease in the available $\mathrm{Cd}^{2+}$ of the cytosol.

The negative impact of $\mathrm{Cd}$ on photosynthesis is well documented (CLIJSTERS; VAN ASSCHE 1985). Rubisco catalyzes the first step in net photosynthetic $\mathrm{CO}_{2}$ assimilation and photorespiratory carbon oxidation (SPREITZER and SALVUCCI 2002). Ferredoxin NADP(H) oxidoreductases (FNRs) catalyze electron transfer between $\mathrm{NADP}(\mathrm{H})$ and ferredoxin (LINTALA et al., 2007). An absence of AtLFNRI led to a decrease in green leaf size, lower chlorophyll content and fewer light-harvesting complex proteins, and a markedly lower PSI/PSII ratio in the mutant than the wild type (LINTALA et al., 2007). In the present study, expression of rubisco (B1, B2), ferredoxinNADP reductase (B7) and ferritin-1 (B8) were all down-regulated after $\mathrm{Cd}$ treatment. These results indicate that $\mathrm{Cd}$ toxicity damaged the photosynthesis system in saffron. Razavizadeh et al. 
(2009) found that the stromal $70 \mathrm{kDa}$ heat shock protein was significantly down-regulated under salinity in tobacco leaves. The authors believed that this down-regulation was likely the cause of the failure to protect cells against salinity. Similar results were also found in this study. Heat shock protein and molecular chaperonin have been found to play vital roles in protein stabilization, folding, assembly and translocation under abiotic stress (KOMATSU; HOSSAIN, 2013). Stromal $70 \mathrm{kDa}$ heat shock-related protein (B3) and chaperonin (B6) were significantly down-regulated (Table 1). The $30 \mathrm{~S}$ ribosomal protein 2 was also down-regulated after $\mathrm{Cd}$ treatment. These results demonstrate that $\mathrm{Cd}$ stress affected the normal functioning of the chloroplast. Moreover, down-regulation of initiation factor $4 \mathrm{~A}$ also affected the level of translation in saffron. In summary, $\mathrm{Cd}$ stress affected the normal functioning of the chloroplast, reducing photosynthesis and translation.

\section{ACKNOWLEDGEMENTS}

This work was supported by the Star Program of the State Ministry of Science \& Technology (2015GA700053), the Zhejiang Natural Science Foundation (LY13B020001) and the Agricultural Project of Zhejiang Public Technology Research (2015C32104).

RESUMO: O cádmio (Cd) é um poluente ambiental global altamente prejudicial. As plantas desenvolveram mecanismos de defesa complexos como uma adaptação contra a toxicidade por Cd. Neste estudo, realizou-se um experimento em vaso para avaliar o perfil proteico do açafrão em resposta ao estresse por Cd. Foi descoberto que quinze proteínas foram supra-reguladas (up-regulated) nas folhas de plantas sob estresse por Cd e foram principalmente relacionados ao metabolismo, transdução de sinal, estresse e resposta de defesa e energia. Foi descoberto ainda que onze proteínas foram infra-reguladas (down-regulated) após tratamento com $\mathrm{Cd}$, incluindo ribulose bifosfato carboxilase oxigenase (RuBisCO), ferredoxina-NADP redutase, uma proteína relacionada com o choque térmico de $70 \mathrm{kDa}$ e três proteínas associadas à síntese de proteínas. Os resultados fornecem informações valiosas sobre o mecanismo molecular do açafrão em resposta à toxicidade do $\mathrm{Cd}$ e a possível utilização de recursos genéticos no desenvolvimento de açafrão tolerante ao $\mathrm{Cd}$ e de baixa acumulação.

PALAVRAS-CHAVE: Metal pesado. Proteoma. Resposta. Fotossíntese. Açafrão.

\section{REFERENCES}

ABOU-ARAB, A. A. K.; ABOU DONIA, M. A. Heavy metals in egyptian spices and medicinal plants and the effect of processing on their levels. Journal of Agricultural and Food Chemistry v. 48, p. 2300-2304, 2000. http://dx.doi.org/10.1021/jf990508p

ASADI, M. H.; ZAFARI, F., SARVEAZAD, A.; ABBASI, M.; SAFA, M.; KORUJI, M.; YARI, A.; MIRAN, R. A. Saffron improves epididymal sperm parameters in rats exposed to cadmium. Nephro-urology monthly, v. 6 , p. e12125, 2014. http://dx.doi.org/10.5812/numonthly.12125

BAH, A. M.; SUN, H.; CHEN, F.; ZHOU, J.; DAI, H.; ZHANG, G.; WU, F. Comparative proteomic analysis of Typha angustifolia leaf under chromium, cadmium and lead stress. Journal of Hazardous Materials v. 184, p. 191-203, 2010. http://dx.doi.org/10.1016/j.jhazmat.2010.08.023

CAO, F.; WANG, R.; CHENG, W.; ZENG, F.; AHMED, IM.; HU, X.; ZHANG, G.; WU, F. Genotypic and environmental variation in cadmium, chromium, lead and copper in rice and approaches for reducing the accumulation. Science of The Total Environment v. 496, p. 275-281, 2014a.

http://dx.doi.org/10.1016/j.scitotenv.2014.07.064

CAO, F.; CHEN, F.; SUN, H.; ZHANG, G.; CHEN, Z. H.; WU, F. Genome-wide transcriptome and functional analysis of two contrasting genotypes reveals key genes for cadmium tolerance in barley. BMC Genomics, $v$. 15, p. 611, 2014b. http://dx.doi.org/10.1186/1471-2164-15-611 
CAO, F.; WANG, N.; ZHANG, M.; DAI, H.; DAWOOD, M.; ZHANG, G.; WU, F. Comparative study of alleviating effects of GSH, Se and Zn under combined contamination of cadmium and chromium in rice (Oryza sativa). Biometals, v. 26, p. 297-308, 2013. http://dx.doi.org/10.1007/s10534-013-9611-9

CARPENTIER, S. C.; WITTERS, E.; LAUKENS, K.; DECKERS, P.; SWENNEN, R.; PANIS, B. Preparation of protein extracts from recalcitrant plant tissues: An evaluation of different methods for two-dimensional gel electrophoresis analysis. Proteomics, v. 5, p. 2497-2507, 2005. http://dx.doi.org/10.1002/pmic.200401222

CLIJSTERS, H.; Van Assche, F. Inhibition of photosynthesis by heavy metals. Photosynthesis Research v. 7, p. 31-40, 1985. http://dx.doi.org/10.1007/BF00032920

DAI, H.; CAO, F.; CHEN, X.; ZHANG, M.; AHMED, IM.; CHEN, Z.; LI, C.; ZHANG, G.; WU, F. Comparative proteomic analysis of aluminum tolerance in tibetan wild and cultivated barleys. PLoS One, v. 8 , p. 5, 2013. http://dx.doi.org/10.1371/journal.pone.0063428

DENG, G.; Li, M.; Li, H.; Yin, L.; Li, W. Exposure to cadmium causes declines in growth and photosynthesis in the endangered aquatic fern (Ceratopteris pteridoides). Aquatic Botany v. 112, p. 23-32, 2014. http://dx.doi.org/10.1016/j.aquabot.2013.07.003

FUJITA, M.; FUJITA, Y.; NOUTOSHI, Y.; TAKAHASHI, F.; NARUSAKA, Y.; YAMAGUCHISHINOZAKI, K.; SHINOZAKI, K. Crosstalk between abiotic and biotic stress responses: a current view from the points of convergence in the stress signaling networks. Current Opinion in Plant Biology v. 9, p. 436-442, 2006. http://dx.doi.org/10.1016/j.pbi.2006.05.014

HALL, J. L.Cellular mechanisms for heavy metal detoxification and tolerance. Journal of Experimental Botany v. 53, p. 1-11, 2002. http://dx.doi.org/10.1093/jxb/53.366.1

HERBETTE, S.; TACONNAT, L.; HUGOUVIEUX, V.; PIETTE, L.; MAGNIETTE, M. L. M.; CUINE, S.; AUROY, P.; RICHAUD, P.; FORESTIER, C.; BOURGUIGNON, J.; RENOU, J. P.; VAVASSEUR, A.; LEONHARDT, N. Genome-wide transcriptome profiling of the early cadmium response of Arabidopsis roots and shoots. Biochimie, v. 88, p. 1751-1765, 2006. http://dx.doi.org/10.1016/j.biochi.2006.04.018

JIN, H.; DO, J.; MOON, D.; NOH, E. W.; KIM, W.; KWON, M. EST analysis of functional genes associated with cell wall biosynthesis and modification in the secondary xylem of the yellow poplar (Liriodendron tulipifera) stem during early stage of tension wood formation. Planta, v. 234, p. 959-977, 2011. http://dx.doi.org/10.1007/s00425-011-1449-1

KIEFFER, P.; DOMMES, J.; HOFFMANN, L.; HAUSMAN, J.; RENAUT, J. Quantitative changes in protein expression of cadmium-exposed poplar plants. Proteomics, v. 8, p. 2514-2530, 2008.

http://dx.doi.org/10.1002/pmic.200701110

KOMATSU, S.; HOSSAIN, Z. Organ-specific proteome analysis for identification of abiotic stress response mechanism in crop. Frontiers in Plant Science v. 4, p. 71, 2013. http://dx.doi.org/10.3389/fpls.2013.00071

KULIK, A.; ANIELSKA-MAZUR, A.; BUCHOLC, M.; KOEN, E.; SZYMANSKA, K.; ZMIENKO, A.; KRZYWINSKA, E.; WAWER, I.; MCLOUGHLIN, F.; RUSZKOWSKI, D.; FIGLEROWICZ, M.; TESTERINK, C.; SKLODOWSKA, A.; WENDEHENNE, D.; DOBROWOLSKA, G. SNF1-Related protein kinases type 2 are involved in plant responses to cadmium stress. Plant Physiology v. 160, p. 868-883, 2012. http://dx.doi.org/10.1104/pp.112.194472

KUNIHIRO, S.; SATIO, T.; MATSUDA, T.; INOUE, M.; KURAMATA, M.; TAGUCHI-SHIOBARA, F.; YOUSSEFIAN, S.; BERBERICH, T.; KUSANO, T. Rice DEP1, encoding a highly cysteine-rich G protein $\gamma$ subunit, confers cadmium tolerance on yeast cells and plants. Journal of Experimental Botany v. 64, p. 45174527, 2013. http://dx.doi.org/10.1093/jxb/ert267 
LEE, K.; BAE, D. W.; KIM, S. H.; HAN, H. J.; LIU, X.; PARK, H. C.; LIM, C. O.; LEE, S. Y.; CHUNG, W. S. Comparative proteomic analysis of the short-term responses of rice roots and leaves to cadmium. Journal of Plant Physiology v. 167, p. 161-168, 2010. http://dx.doi.org/10.1016/j.jplph.2009.09.006

LINTALA, M.; ALLAHVERDIYEVA, Y.; KIDRON, H.; PIIPPO, M.; BATTCHIKOVA, N.; SUORSA, M.; RINTAMÄKI, E.; SALMINEN, T. A.; ARO, E.; MULO, P. Structural and functional characterization of ferredoxin-NADP+-oxidoreductase using knock-out mutants of Arabidopsis. The Plant Journal v. 49, p. 1041-1052, 2007. http://dx.doi.org/10.1111/j.1365-313X.2006.03014.x

MACCARONE, R.; DI MARCO, S.; BISTI, S. Saffron supplement maintains morphology and function after exposure to damaging light in mammalian retina. Investigative Ophthalmology \& Visual Science v. 49, p. 1254-1261, 2008. http://dx.doi.org/10.1167/iovs.07-0438

RANA, N. K.; MOHANPURIA, P.; YADAV, S. K. Expression of tea cytosolic glutamine synthetase is tissue specific and induced by cadmium and salt stress. Biologia Plantarum, v. 52, p. 361-364, 2008. http://dx.doi.org/10.1007/s10535-008-0075-7

RAZAVIZADEH, R.; EHSANPOUR, A. A.; AHSAN, N.; KOMATSU, S. Proteome analysis of tobacco leaves under salt stress. Peptides, v. 30, p. 1651-1659, 2009. http://dx.doi.org/10.1016/j.peptides.2009.06.023

SHAMSA, A.; HOSSEINZADEH, H.; MOLAEI, M.; SHAKERI, MT.; RAJABI, O. Evaluation of Crocus sativus L. (saffron) on male erectile dysfunction: A pilot study. Phytomedicine, v. 16, p. 690-693, 2009. http://dx.doi.org/10.1016/j.phymed.2009.03.008

SPOKEVICIUS, A. V.; SOUTHERTON, S. G.; MACMILLAN, C. P.; QIU, D.; GAN, S.; TIBBITS, J. F. G.; MORAN, G. F.; BOSSINGER, G. $\beta$-tubulin affects cellulose microfibril orientation in plant secondary fibre cell walls. The Plant Journal v. 51, p. 717-726, 2007. http://dx.doi.org/10.1111/j.1365-313X.2007.03176.x

SPREITZER, R. J.; SALVUCCI, M. E. Rubisco: structure, regulatory interactions, and possibilities for a better enzyme. Annual Review of Plant Biology v. 53, p. 449-475, 2002.

http://dx.doi.org/10.1146/annurev.arplant.53.100301.135233

URAGUCHI, S.; FUJIWARA, T. Cadmium transport and tolerance in rice: perspectives for reducing grain cadmium accumulation. Rice, v. 5, p. 1-8, 2012. http://dx.doi.org/10.1186/1939-8433-5-5

VESCOVI, M.; ZAFFAGNINI, M.; FESTA, M.; TROST, P.; LO SCHIAVO, F.; COSTA, A. Nuclear accumulation of cytosolic glyceraldehyde-3-phosphate dehydrogenase in cadmium-stressed Arabidopsis roots. Plant Physiology, v. 162, p. 333-346, 2013. http://dx.doi.org/10.1104/pp.113.215194

VESELOV, D.; KUDOYAROVA, G.; SYMONYAN, M.; VESELOV, S. Effect of cadmium on ion uptake, transpiration and cytokinin content in wheat seedlings. Bulgarian Journal of Plant Physiology v. 29, p. 353$359,2003$.

XU, C.; SIBICKY, T.; HUANG, B. Protein profile analysis of salt-responsive proteins in leaves and roots in two cultivars of creeping bentgrass differing in salinity tolerance. Plant Cell Reports v. 29, p. 595-615, 2010. http://dx.doi.org/10.1007/s00299-010-0847-3 